\title{
Hexokinase and carnitine palmitoyltransferase activities in flight muscles of grasshopper Valanga nigricornis(burm.)
}

\begin{abstract}
1. The activities of hexokinase and carnitine palmitoyltransferase (CPT) activities were assayed in flight muscle mitochondria of Valanga nigricornis.

2. Kinetic analysis of the enzyme activities yielded the following information: for hexokinase, its $\mathrm{Km}$ (glucose) is $150 \mathrm{\varepsilon M}$ while its Vmax is $2.5 \mathrm{\varepsilon mol} / \mathrm{min} / \mathrm{mg}$ protein; the corresponding data for CPT are $\mathrm{Km}$ (palmitoylCoA) of $39 \varepsilon \mathrm{M}$ and Vmax of 22.2 $\mathrm{nmol} / \mathrm{min} / \mathrm{mg}$ mitochondrial protein.

3. Under conditions of equivalent rates of ATP production the hexokinase-CPT activity ratio is 64, suggesting that although V. nigricornis is a ñmixedò fuel utilizer, it appears that carbohydrate oxidation constitutes the predominant energy source.
\end{abstract}

Keyword: Hexokinase; Carnitine palmitoyltransferase; Valanga nigricornis 